\title{
The Potyviridae Cylindrical Inclusion Helicase: A Key Multipartner and Multifunctional Protein
}

\author{
M. Sorel, ${ }^{1}$ J. A. Garcia, ${ }^{2}$ and S. German-Retana ${ }^{1}$ \\ ${ }^{1}$ INRA, UMR BFP 1332, Equipe de Virologie, CS 20032, 33882 Villenave d'Ornon, France; ${ }^{2}$ Departamento de Genética \\ Molecular de Plantas, Centro Nacional de Biotecnología (CNB-CSIC), Campus Universidad Autónoma de Madrid, \\ 28049 Madrid, Spain
}

Submitted 13 November 2013. Accepted 14 December 2013.

A unique feature shared by all plant viruses of the Potyviridae family is the induction of characteristic pinwheelshaped inclusion bodies in the cytoplasm of infected cells. These cylindrical inclusions are composed of the viralencoded cylindrical inclusion helicase (CI protein). Its helicase activity was characterized and its involvement in replication demonstrated through different reverse genetics approaches. In addition to replication, the CI protein is also involved in cell-to-cell and long-distance movements, possibly through interactions with the recently discovered viral P3N-PIPO protein. Studies over the past two decades demonstrate that the CI protein is present in several cellular compartments interacting with viral and plant protein partners likely involved in its various roles in different steps of viral infection. Furthermore, the CI protein acts as an avirulence factor in gene-for-gene interactions with dominant-resistance host genes and as a recessive-resistance overcoming factor. Although a significant amount of data concerning the potential functions and subcellular localization of this protein has been published, no synthetic review is available on this important multifunctional protein. In this review, we compile and integrate all information relevant to the current understanding of this viral protein structure and function and present a mode of action for CI, combining replication and movement.

The Potyviridae family includes the genus Potyvirus, one of the largest groups of plant viruses, and seven additional genera (Brambyvirus, Bymovirus, Ipomovirus, Macluravirus, Poacevirus, Potyvirus, Rymovirus, and Tritimovirus) that are defined on the basis of genomic relatedness, genome organization, and mode of transmission. According to the Ninth Report of the International Committee on Taxonomy of Viruses (Adams et al. 2011), the Potyviridae family is composed of 176 virus species, of which 146 belong to the Potyvirus genus. These worldwide pathogens infect a large range of hosts, including important agricultural crops. Due to their economic and scientific importance, two Potyvirus spp., Plum pox virus (PPV) and Potato virus $Y$ (PVY), were recently listed in the top 10 most important plant viruses in molecular pathology (Scholthof et al. 2011).

Corresponding author: S. German-Retana; E-mail: german@bordeaux.inra.fr

(C) 2014 The American Phytopathological Society
Members of the Potyviridae family have non-enveloped flexuous filamentous particles of 680 to $900 \mathrm{~nm}$ in length and 11 to $13 \mathrm{~nm}$ in diameter. The encapsidated genome is formed by a positive, single-stranded RNA of approximately 10,000 nucleotides, except for the bymoviruses, whose genome consists of two RNAs. The uncapped genomic RNA has a viral protein linked to the $5^{\prime}$ end, contains $5^{\prime}$ and $3^{\prime}$ terminal untranslated regions (about 100 to 150 and 200 nucleotides, respectively), and a large open reading frame (ORF) encoding a polyprotein processed co- and post-translationally into $10 \mathrm{mul}-$ tifunctional proteins: $\mathrm{P} 1$, helper component proteinase $(\mathrm{HC}-$ Pro), P3, 6K1, cylindrical inclusion (CI) protein, 6K2, viral genome-linked protein (VPg), nuclear inclusion a (NIa), nuclear inclusion $\mathrm{b}(\mathrm{NIb})$, and capsid protein $(\mathrm{CP})$ (Urcuqui-Inchima et al. 2001) (Fig. 1). A small ORF called "pretty interesting Potyviridae ORF" (PIPO) embedded in the P3 cistron is expressed as a functional protein fused to the $\mathrm{N}$-terminal region of P3 (P3N-PIPO), presumably via a ribosomal frameshift during translation or transcriptional slippage during RNA synthesis (Chung et al. 2008; Vijayapalani et al. 2012; Wen and Hajimorad 2010). Based on similarities of genome structure and some protein sequences, the Potyviridae spp. are considered as distantly related to the plant viruses of the family Secoviridae and to animal viruses of the family Picornaviridae as well as other families of the order Picornavirales (International Committee on Taxonomy of Viruses website), in the proposed supergroup of Picorna-like viruses (Goldbach et al. 1994).

A unique feature shared by all species of Potyviridae is the induction of characteristic pinwheel-shaped inclusion bodies in the cytoplasm of infected cells (Edwardson 1974). These cylindrical inclusions are composed of the virus-encoded CI protein and are one of the key features for diagnosis of Potyviridae spp. infection. Other types of inclusions can be seen in Potyviridae-infected plant cells, such as nuclear inclusions and amorphous inclusions, but they are neither produced by all the Potyviridae members nor exclusive to them. Although inclusion bodies associated with virus infection are often considered to be inactive storage forms of particular proteins, it seems unlikely that highly ordered structures such as pinwheels could only be random protein aggregates with no function in the viral infection. The CI protein forming these inclusions is a multifunctional protein whose involvement in virus replication and cell-to-cell movement has been demonstrated. CI protein may also participate in the systemic movement of the virus and contribute to symptom determination, elicit dominant resistance responses, and facilitate the breaking of recessive resistance. 
Additionally, a significant number of viral and plant factors located in different subcellular compartments of the plant cell have been demonstrated to interact with this protein. In this review, we present an integrated view of the CI protein's localization, interacting partners, and activities in order to develop a model of its action that combines the replication and movement functions of this protein during the viral infection process.

In this review, the abbreviated term "CI" will be used to design the viral protein that forms the cylindrical inclusions, whereas we will refer to these structures without abbreviation.

\section{Cylindrical inclusions: The main ultrastructural diagnostic criterion for Potyviridae infection.}

In the 1950s, improvement of histological techniques for electron microscopy based on negative staining and transmission electron microscopy enabled plant virologists to observe viral particles in plant tissues and ultrastructural changes induced by viruses. In 1958, the potyvirus PVY was first observed in infected leaves of Datura metel (David-Ferreira and Borges 1958). Filamentous virus particles of constant width were observed, together with cylindrical inclusions in the cytoplasm of infected cells. Similar structures were further described in various plant hosts infected by different members of the Potyviridae family, such as Tulip breaking virus, Turnip mosaic virus (TuMV), Tobacco etch virus (TEV), Wheat streak mosaic virus (WSMV), Bean yellow mosaic virus, Watermelon mosaic virus, Lettuce mosaic virus (LMV), Bean common mosaic virus, and Sugarcane mosaic virus (Edwardson 1966). Some of those inclusions were described as pinwheels and others as bundles, which led to a misinterpretation that they represented two distinct types of inclusion bodies. In 1966, Edwardson performed series of cross and longitudinal sections of tobacco leaves infected with TEV and demonstrated that pinwheels and bundles were two sides of the same structure. Cylindrical inclusions were described as "curved or flat striated protein plates with their inner edges converging around the central axis of the cylinder and their outer edges diverging to form boundary of the cylinder" (Edwardson 1966). Scrolls, tubes, and laminated aggregates were also associated with the pinwheel bundle and, thus, the potyviral cylindrical inclusions were also usually known as pinwheels. After purification of the cylindrical inclusions (Hiebert et al. 1971), antisera raised against them did not react with the $\mathrm{CP}$ protein or with host proteins (Purcifull et al. 1973). Hence, nonstructural proteins encoded by the viral genome were hypothesized to comprise these cylindrical inclusions. This was supported by the identification of the CI protein among the in vitro translation products of Pepper mosaic virus genomic RNA (Dougherty and Hiebert 1980).
Cylindrical inclusions are characteristic of Potyviridae spp. infection and their detection by electron microscopy is used as a diagnostic tool (Edwardson 1974). Based on variations in shape and size, four subgroups of inclusions were established in order to help identify viral species (Edwardson and Christie 1978; Edwardson et al. 1984). However, further ultrastructural analysis revealed that the forms of the cytoplasmic inclusions were not valid cytological criterion for distinguishing species because, as reported by Edwardson (1992), different isolates of the same virus could induce different inclusions. Today, the identification of new viral species is based on the degree of similarity of their genome sequences along with biological characteristics, such as host range, vector, and pathogenicity (Adams et al. 2005).

Despite the abundance of literature describing the structural aspects of the pinwheel inclusions, the exact mechanism for their formation is still unknown and it is not clear whether inclusions form spontaneously or if their assembly requires the activity of other viral or host proteins (Graybosch et al. 1989; Wittner et al. 1998). Self-interaction was demonstrated in planta for the full-length CI protein of PPV by a bimolecular fluorescence complementation system (BiFC) (Zilian and Maiss 2011) and for the CI protein of the tritimovirus WSMV through an in vitro binding assay using a glutathione- $S$-transferase fusion protein expressed in bacteria and in vitro translation products (Choi et al. 2000). In yeast two-hybrid (Y2H) assays, positive self-interactions were detected for N-terminal fragments of the PPV CI protein (Gómez de Cedrón et al. 2006; López et al. 2001). However, in contrast, the C-terminal region of the WSMV CI protein was shown to be involved in the self-interaction (Choi et al. 2000). Therefore, it seems that the Potyviridae CI proteins are able to interact in the absence of other viral proteins through their C-terminal and $\mathrm{N}$-terminal ends.

Previous work tends to demonstrate that CI self-assembly is virus specific, because mixed infections with members of different genera of Potyviridae failed to form hybrid cylindrical inclusions (Langenberg 1991, 1993). To assess the possible auto-formation of pinwheels, heterologous expression of $\mathrm{CI}$ protein from diverse potyviruses in transgenic Nicotiana tabacum (under the control of Cauliflower mosaic virus [CaMV] $35 \mathrm{~S}$ or rbcS1 promoter) and in N. benthamiana (under the control of CaMV 35S promoter) was performed; no cylindrical inclusion could be detected in those transgenic plants, despite a great disturbance of cellular inter- and intra-arrangements (Graybosch et al. 1989; Maiti et al. 1993; Shand et al. 2009; Wittner et al. 1998). This suggests that either the expression level of transgenic CI was insufficient or other viral partners were needed to form pinwheels, in spite of the capacity of the CI protein to self-interact.

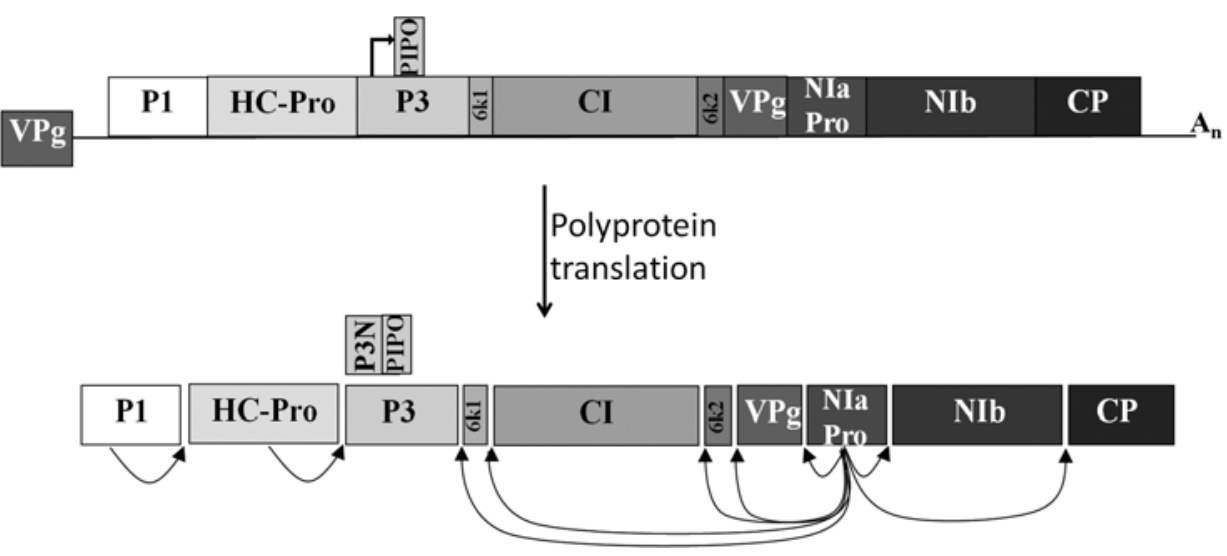

Fig. 1. Genomic organization of potyviruses. 
Observation of Sweet potato feathery mottle virus-infected Iris setosa leaves at various time points after infection via aphids, allowed Lawson and co-workers (1971) to provide a comprehensive description of the formation of cylindrical inclusions. Inclusions first appeared in the parenchyma cells of the vascular bundle and in phloem cells, then in mesophyll cells, where they were close to the plasmalemma and perpendicular to the cell wall. In another article from the same group, Lawson and Hearon (1971) demonstrated that the inclusions associated with plasmodesmata (PDs). The association of cylindrical inclusions with PDs was also observed in wheat root cells newly infected with WSMV and Wheat spindle streak mosaic virus (Langenberg 1986, 1993), in newly emerged leaves of tobacco infected with Tobacco vein mottling virus (TVMV) (Rodríguez-Cerezo et al. 1997), and at the front of infection of Pea seed-borne mosaic virus (PSbMV) in pea cotyledons (Roberts et al. 1998) (Fig. 2). In all cases, a close association of CI with $\mathrm{CP}$ was observed. In all those studies, at early stages of the infection ( 1 to 5 days), pinwheels were intact and close to the plasma membrane; no structures were observed in the cytoplasm. In SFMV-inoculated leaves, the PD-associated inclusions were detached partially from the plasmalemma and associated with the endoplasmic reticulum (ER) at 7 days after inoculation (dai) (Lawson et al. 1971). Pinwheels that were completely cytoplasmic began to disintegrate, forming loops and circles in the cytoplasm (Fig. 2). At 10 dai, some membrane-like aggregates appeared to result from the association of pinwheel septa becoming parallel with ER-derived vesicles. These structures were also observed by Weintraub and Ragetli (1970) in leaf cells of Dianthus barbatus infected with Carnation vein mottle virus and were associated with virus-like particles. The physical association between inclusions and virus particles was later further supported by co-purification of virus particles with CI protein (GabrenaiteVerkhovskaya et al. 2008; Hiebert and McDonald 1973).

Recently, cylindrical inclusions have been described in phloem parenchyma and companion cells of tobacco and pepper plants infected with PVY, as well as in the xylem tracheary elements (Otulak and Garbaczewska 2012). Similarly to those previously observed in mesophyll cells, these inclusions were in close proximity to the plasmalemma, opposed to PD.

Thus far, although one would think that the aggregation of waste proteins would not require such highly arranged structures, no clear function has been assigned to the cylindrical inclusions other than a potential role in movement (discussed below). Furthermore, it was shown by electron microscopy and immunogold labeling that the $\mathrm{CP}$ and the $\mathrm{P} 3$ proteins of TVMV and the P1 protein of PVY are associated with cylindrical inclusions in infected tobacco leaves and protoplasts (Ammar et al. 1994; Arbatova et al. 1998; Rodríguez-Cerezo et al. 1993), suggesting a possible role of the cylindrical inclusions as a scaffold structure related to the virus replication.

\section{CI protein: A major viral replication factor.}

CI and replication factories. Proliferation of ER membranes in infected cells leading to the formation of viral factories was observed for several viruses, including potyviruses (den Boon and Ahlquist 2010; Schaad et al. 1997; Zechmann et al. 2003). For TuMV and TEV, it was shown that replication and translation of the viral genome could be coordinated into specialized cytoplasmic vesicles originating from the ER and induced by the viral membrane anchoring protein $6 \mathrm{~K} 2$ or $6 \mathrm{~K} 2-\mathrm{VPg}-\mathrm{Pro}$ precursor (Beauchemin and Laliberté 2007; Cotton et al. 2009; Schaad et al. 1997). The biogenesis of the replication vesicles occurs at ER exit sites in a COPI- and COPII-dependent manner (Wei and Wang 2008), potentially stabilizing the vesicles. In $N$. benthamiana cells infected with TuMV:6K2-green fluo- rescent protein, $6 \mathrm{~K} 2$ vesicles were observed to co-localize with chloroplasts and induce their invagination (Wei et al. 2010a). Viral RNA, double-stranded (ds)RNA, and viral replicase components were detected in these chloroplast-bound $6 \mathrm{~K} 2$ vesicles, suggesting a sequential recruitment of ER and chloroplasts for potyvirus replication. More recently, an integrative model was proposed by Grangeon and associates (2012), who described the formation during TuMV infection of a large perinuclear globular structure: an amalgamation of ER, Golgi bodies, COPII coatamers, chloroplasts, and viral replication complex components. ER and Golgi bodies in this globular structure remained connected to the host secretory pathway and $6 \mathrm{~K} 2$ vesicles appeared to emerge from and be functionally linked to this structure, probably for intra- and intercellular movement purposes (Agbeci et al. 2013).

In 1990, Calder and Ingerfeld observed that pinwheel inclusions induced by PSbMV infection were in close proximity to the rough ER in pea-infected leaf cells. Moreover, they observed vesicles originating from pinwheel-associated ER: some were light and others were electron dense. Similar vesicles were observed in TuMV-infected cells (Grangeon et al. 2012). This led to the hypothesis that the CI protein of the inclusions might be associated with these vesicles, although this hypothesis has not received further experimental support. Analysis of the proteolytic processing of the Potato virus A (PVA) polyprotein performed by virus-encoded proteinases in insect cells showed that cleavage between $\mathrm{CI}$ and $6 \mathrm{~K} 2$ was slow (Merits et al. 2002). Indeed, the unprocessed CI-6K2 intermediate was detected in infected leaves associated with the membrane fraction, while the fully processed CI protein was associated with the soluble fraction. Hence, the $6 \mathrm{~K} 2$ fusion would provide membrane anchoring for CI loading in the vesicles. In fact, im-

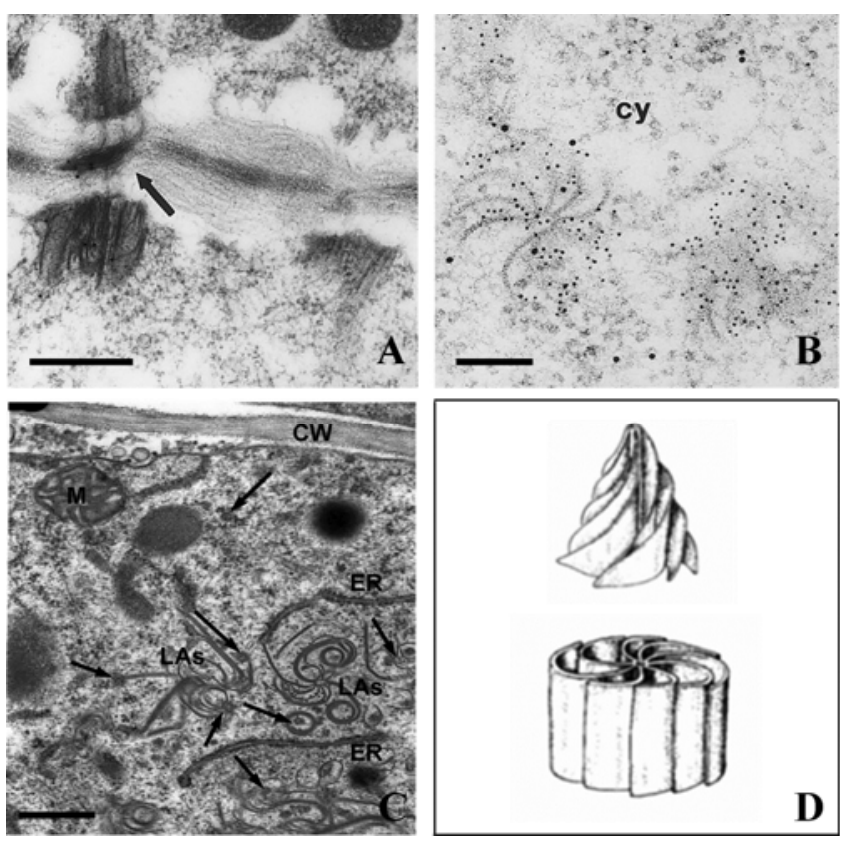

Fig. 2. Various morphologies of cylindrical inclusions (CI). A, Detection of PSbMV CI at both sides of the plasmodesmata connecting two pea cotyledon cells at the front of infection (from Roberts et al. 1998). Bar = $500 \mathrm{~nm}$. The arrow indicates the presence of capsid protein in the plasmodesmata cavity. B, Immunodetection of CI proteins in pinwheels detached from the cell wall (from Rodriguez-Cerezo et al. 1997). Bar $=100 \mathrm{~nm}$; cy = cytoplasm. C, Observation of pinwheels disintegrating, some of them being connected to endoplasmic reticulum (ER). Vesicles are detected in the vicinity of condensing inclusions (arrows) (from Otulak and Garbaczewska 2012). Bar $=1 \mu \mathrm{m}, \mathrm{CW}=$ cell wall, $\mathrm{LA}=$ pinwheel inclusions, $\mathrm{M}=$ mitochondrion, Pme = Palisade Parenchyma. D, Three-dimensional schematic representation of conical and pinwheel inclusions (Astier et al. 2001). 
munolocalization assays performed on $N$. benthamiana leaves infected with TuMV demonstrated that ER-derived vesicles were associated with $\mathrm{CI}$ and that all dsRNA punctates detected in these vesicles co-localized with the CI but not all CI colocalized with the dsRNA (Cotton et al. 2009). The vesicles contained other viral proteins associated with RNA synthesis (VPg, RNA-dependent RNA polymerase [RdRP] NIb) and RNA replication was demonstrated by BrdU staining (Cotton et al. 2009). Alternatively, CI protein expressed transiently in TuMV-infected cells was shown to accumulate as spike-like structures in proximity to these vesicles, in addition to structures penetrating the cell wall (Wei et al. 2010a). These observations suggested that, inside the vesicles, the CI could be involved in viral replication but exhibit another role in their vicinity. For example, interactions between the CI of the vesicles (replication complexes) and the CI of the cylindrical inclusions (transport engine) could facilitate the transport of the RNA-CP complex (or virions) through the PDs.

Furthermore, host factors involved in mRNA translation were detected in these vesicles, among them eIF(iso)4E, whose lettuce homolog eIF4E was demonstrated to interact with the Cterminal part of the LMV CI protein (Tavert-Roudet et al. 2012). In the case of TuMV infection, the presence of eIF(iso)4E in these vesicles suggests a role of this protein in RNA replication, and also a close physical relationship between translation and replication of the viral RNA (Beauchemin and Laliberté 2007). The authors hypothesize that $6 \mathrm{~K} 2-\mathrm{VPg}-\mathrm{Pro}$, another polyprotein intermediate cleavage product, not only induces the formation of membrane vesicles that house replication complexes but also may be responsible for the coupling of viral RNA translation and replication through interaction with both eIF(iso)4E and viral RdRP within a single vesicle. An alternative hypothesis states that the interaction of CI with eIF4E which, in turn, interacts with eIF4G would facilitate intracellular movement of those vesicles via eIF4G association with microtubules (Wang and Krishnaswamy 2012). Indeed, it has been demonstrated that the TuMV-induced $6 \mathrm{~K} 2$ vesicles are very motile and that an intact microfilament network and a functional secretory pathway are important for intracellular movement and the establishment of a productive infection (Agbeci et al. 2013; Cotton et al. 2009; Wei et al. 2010a). However, the involvement of microtubules in the vesicle movement is questioned by the results of Cotton and associates (2009), because they showed that drugs that disassemble microtubules did not significantly affect TuMV infection.

The presence of CI in the virus-induced vesicles was also supported by the fact that $\mathrm{Y} 2 \mathrm{H}$ interactions have been demonstrated between the CI protein and host proteins originating from the ER and chloroplast (Bilgin et al. 2003; Jiménez et al. 2006). One study has shown that CI from TEV, as well as the P50 helicase of the tobamovirus Tobacco mosaic virus (TMV), interacts with the ER stress-related $\mathrm{P} 58^{\mathrm{IPK}}$ protein of Arabidopsis thaliana and $N$. benthamiana. In a second study, Jimenez and associates (2006) identified the chloroplastic photosystem I PSI-K subunit from A. thaliana and $N$. benthamiana as a protein that interacts with the CI protein from PPV and TVMV. Although the enhancement of chloroplast associated ATPase activity in maize plants infected by Maize dwarf mosaic virus (MDMV) (Chen et al. 1994) was probably the result of global physiological changes caused by the infection, the possibility that helicase activity of the CI protein in the chloroplast compartment contributed to the observed effect cannot be ruled out. In this regard, in the same study, ATPase activity was also observed at the end of the pinwheels arms, in the ER-derived vesicles, and throughout the PD.

Helicase activity. Potyviridae CI proteins possess highly conserved amino acids in their amino-terminal and central do- mains (Fig. 3, amino acids 35 to 360) that are organized in 12 characteristic sequence motifs (Fairman-Williams et al. 2010; Gorbalenya and Koonin 1993) with great similarity to helicase proteins of the super family 2 (SF2) (Fairman-Williams et al. 2010; Kadaré and Haenni 1997; Laín et al. 1989). Interestingly, whereas Potyviridae spp. belong to the picorna-like cluster of RNA viruses, whose putative helicases belong to the SF3 group, their CI proteins are more similar to the viral helicases of the SF2 group in the family Flaviviridae (Laín et al. 1989).

An RNA helicase activity was first demonstrated for PPV CI purified from N. clevelandii-infected leaves (Laín et al. 1990, 1991). The authors showed that the purified CI protein displayed a poly-A-stimulated ATPase activity involved in unwinding RNA in a $3^{\prime}$ to $5^{\prime}$ direction. Furthermore, a PPV CI/maltosebinding fusion protein synthesized in Escherichia coli retained NTPase and RNA helicase activities in vitro (Fernández et al. 1995). NTPase and RNA helicase activities of the CI protein of Tamarillo mosaic virus were also characterized (Eagles et al. 1994). One hypothesis stemming from these results is that CI protein, through its RNA helicase activity, plays a role in viral replication by unwinding RNA secondary structure or possibly recruiting viral RNA for replication and transfer to the translation machinery. Fernández and coworkers (1997) demonstrated that motif V of the PPV CI, which is involved in NTP hydrolysis and necessary for helicase activity, was essential for systemic viral infection and virus replication in protoplasts. Likewise, any mutation or insertion within the conserved helicase motifs of TVMV, PVA, or TEV abolished or drastically lowered virus replication, further underscoring the strong correlation between helicase activity and virus replication (Carrington et al. 1998; Kekarainen et al. 2002; Klein et al. 1994) (Fig. 3).

Reverse genetics experiments also uncovered permissive mutations or insertions all along the CI coding region that apparently do not disturb the structural arrangement of the protein. Some insertions in the C-terminal part of the CI protein of TVMV or TEV were deleterious for virus replication in tobacco plants, even though the removal of the C-terminal 103 amino acids (aa) of the protein from PPV CI did not affect its RNA helicase activity in vitro (Fernández et al. 1995). Thus far, no function has been assigned to the $\mathrm{C}$-terminal region of the $\mathrm{CI}$ protein, although it is a prominent feature, extending beyond the conserved domains. Hence, the C-terminal part of the CI protein might be a regulatory module, necessary in the context of a plant infection; for example, by brokering interaction with other proteins involved in virus replication.

\section{CI is required for virus movement within the plant.}

CI inclusions flirting with plasmodesmata. As mentioned above, ultrastructural analyses revealed that cylindrical inclusions were localized in the vicinity of the plasmalemma at early times of infection. CI was associated with cone-shaped structures close to PD, together with $\mathrm{CP}$ and viral RNA (Calder and Ingerfeld 1990; Langenberg 1993; Lawson et al. 1971; Roberts et al. 1998; Rodríguez-Cerezo et al. 1997). In this regard, one could hypothesize that $\mathrm{CI}$ acts as a movement protein (MP) by increasing the size exclusion limit (SEL) of PD. Nevertheless, this was not supported by microinjection experiments performed by Rojas and associates (1997) with Bean common mosaic necrosis virus CI. One major advance in understanding the relevance of PD localization in the function of $\mathrm{CI}$ was made with the recent discovery of P3N-PIPO (Chung et al. 2008; Vijayapalani et al. 2012). This protein was shown to be localized at the PD and was able to promote its own movement between cells (Vijayapalani et al. 2012; Wei et al. 2010b). Anchoring of P3N-PIPO to PD was demonstrated to be dependent on its interaction with myristoylated plasma 
SV-DEIIDLFDEKKETIDFEIEGKELYSSRVVDSTFSKWWDNQ VRGNTMAHYRTEGHFMTFTRETAA SVAAEIAHNEYRDILLQ L-DDIEDILDEKKLTVDFVLQSNEVAPTVPFDSTFEKWWTNQ ET GNVIPHYRTEGHFLEFTRENAAHIANEVMHGSHQDILIR SAVGS GKS PGLPFHL SL-DDI GPTLEEKNMT IDFDLDTDTIVGKS I I GHTFKEWWDVQ_NTNR IVPHYRTEGHFMEFTRANAPT IAHQIAHDLHTDIMLR SAVGSGKS PGLPYHL SL-DDYVTT FDD-NMT INLELNMDELHKT SLPGVTFKQWWNNQ ISRGNVKPHYRTEGHFMEFTRDTAASVASEISHSPARDFLVR SAVGS GKS FGLPYHL SL-DT IVPTQEEKNMVIDFELDSDTAHT PQMQEQTF SDWWSNQ LANNRVVPHYRTEGYFMQFTRNTASAVSHQIAHNEHKDI I LM FAVGSGKS IGLPTNL SL-DEIQS IDEDKKLT IDFDLETNKESS SVSFDVKFEAWWNRQ EQNRVIPHYRST GEFLEFTRETAAKIANLVAT SSHTEFLIR FAVGSGKS FGLPHHL SL-DDVIKNFDERNEI IDFELSEDT IRT SSVLDTKFSDWWDRQ LQMGHTLPHYRTEGHFMEFTRATAVQVANDIAHSEHLDFLVR SAVGSGKS FGLPVHL TLNDIEDDLSERNLFVDFELSSDGDMLQQLPAEKTFASWWSHO_SRGFTIPHYRTEGKFMTFTRATATEVAGKIAHESDKDILLMEAVGSGKS FGLPYHL

HRKGGVLLIEPTRPLA RNVYKQLGS SPFHLSPNLRMPGSEKGSSQVTVA TSGYAL IFIANNAQSLKAYDFIIF PECHVFDASAMAFRCLLQEFEYQGKI SKKGHVLLIEPTRPLA ENVCKQLRGQPFNVNPTLRMR GM TTFGSTPITVMISGYAL FFLANNPTYLDNYKCIIF FECHVHDASAMAFRCLLSEYSYPGKI SKKGTVLLI EPTRPLA ENVTKQLKSDPFHVS PTLRMR GMAVFGST P IHVMTT GFAL IYLANNLKMLSTYDFIII IEFHV IDSNAIALRNLLHEHNYQGKL SKRGRVLMI EPTRPLT DNMHKQLRSEP FNCFPTLRMR GK TTFGSPITVMTGSFAL IHFARNIAEVKTYDFVII FCHV DDASAIAFRNLLFEHEFEGKV CKFGGVLLIEPTRPLA ENVTKQMRGSP FFASPTLRMRNL TTFGSSPITVMITGFAL FFFANNVKEFDRYQFIIF FEFHV.DSNAIAFRNLCHEY SYNGKI SKKGKVLLI EPTRPLA ENVSKQLSFEP FYHNVTLRMF GM $\$$ KFGSSNIVVMI SGFAF FYYVNNPQQLSD FDFI I I DECHVRDSPT IAFNCALKEFEF SGKL SVAGSVLLIEPTRPLA ENVFKQLSSEP FFKKPTLRMR GN IFGSSPISVMI SGFAL IYFANNRSQLAQFNFVIF FECHVEDPSAMAFRSLLSVYHQACKV SRKGNVLLI EPTRPLA FNVHKQLSQAP FHQNTTLRMR GL FAFGSAP ISVMIS SFAL TYFANNRMRIEEFDFVIFDECHVFDANAMAMRCLLHECDYSGKI $\mathrm{Ia}, \mathrm{Mg}^{2+}$ binding

IKV SATP GRKLDFKPMHMVDIATENELSIQQFVQGQGTGVNCDATKKGDN ILVYVSS INEVDMLSKMLNDKGYKVTKVDGRTMK.GSVEVETVGTPQRK LKV SATP GHEVDFKTQKEVKV IVEESLSFQQFV SNLGT GCNSDI LKHGVNVLVYVAS INEVDTLSKLLTDRSFKVSKVDGRTMK GNVEIPT SGTQAKP IKV SATP GREVEF STQY PVEIRVEDQVSFQDFVKAQGNGSNLDLT SKCDNLLVYVAS INEVDQLSKLLLERHFLVTKVDGRSMK.GQVEIITKGSANKK

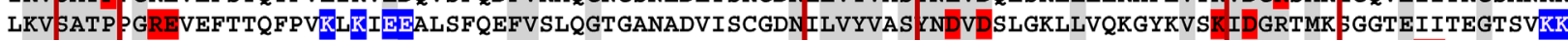
IKVPAT P GRECDLTTQY PVELL IEEQLSLRD FVDAQGTDAHADVVKK GDNILVYVAS INEVDQLSKMLNERGFLVTKVDGRTMK.GGVEIITKGSS IKK IKV SATP GRECEFTTQHPVKLKVEDHLSF QNFVQAQGT GSNADMIQHGNN LLVYVAS INEVDQLSRLLTEKHYKVTKVDGRTMQ IGNVE IATTGTEGKP LKV SAT P JGREVEFT TQQPVKL IVEDT LSF QS FVDAQGSK TNADVVQF GSN VLVYVS SNEVDTLAKLLTDKNMMVTKVDGRTMK IGCLE IVTKGT SARP

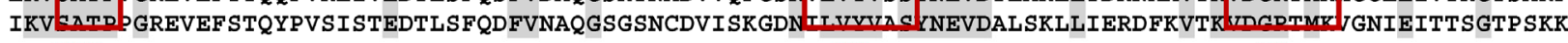
III

IV

HFV VATNI I ENGVTLD VDVVVDFGOKVVPILDSEHRMIRYTKKSITYGERI RRVGRVGR NKAGSAIRIGSTEMGTEEIPASIATEAAFLCFTYGLPVMIS HFVVATNI IENGVTLD LDVVVDFGI KVVPVLDIDNRLVRYTKKSISYGERI RRLGRVGR VKSGAALRI GFTEKGLTQIPPI IATEAAFLCFTYGL PVMTN HFI VATNI IENGVTLD LDA VIDF GM KVVPFLD SDNRMISYNKV S I SYGERI RRLGRVGR NKAGVALRIGHTEKGI SDVPVVIATQAAFLCFVYGLPISTQ HFI VATNI IENGVT I EDVVVDF GTKVVPVLDVDINRAVQYNKTVVSYGERI RKLGRVGR IKEGVALRIGQTNKTLVEI P EMVATHAAFLCFMYNL PVTTQ HFI VATNI I NNGVTLD DVVVDF GI KVVPNLD SDNRLVSYCKIPI SLGERI RRFGRVGR NKPGVALRIGETIKGLVEIP SMIATEAAFLCFVYGL PVTTQ HFI VATNI IENGVTLD LDC VIDFGI KVVATLDTDNRCVRYNKQSVSYGERI RRLGRVGR EKPGFALRIGHTGKGVEEVPEF IATEAAFLSFAYGLPVTTQ HFV VATNI I ENGVT LD LDVVVDF GI KVS PFLDIDNRS IAYNKVSVSYGERIRRLGRVGR KKGVALRIGHTEKGI IEI P SMVATEAALACFAYNLPVMTG HFI VATNI IENGVTLD IDV VADF GTKVLPYLDTDSRMLSTTKT INYGERI RRLGRVGR FKP GHALRIGHTEKGLSEVP SCIATEAALKCFTYGLPVITN $\mathrm{Va}$ $\mathrm{Vb}$

NVST SVLGNCTVRQARTMQKFELSPFFMVDLVHHDGT IHPAINSLLKQFKLKESDIKLSTLAIPNAVTTFWKSAREYNSLGARTTIDDAAKIPFMIKDVP GVSTSLLAMCTVKQARTMQQFELSPFYTVALVRFDGTMHQEIFRLLKSYRLRDSEVILNKLAIPNSNVCGWMSVRDYKRQGCNLDLDENIRVPFYVKDIP SVTTQVLSNVTLKQARTMVQFELPIFYMAHLVRYDGTMHPAIHNELKKYKLRDSEIQLSKLAIPSKCVPIWMTGKAYRLLTHNSQIPDDVRVPFLTKEIP SVSTTLLENATLLQARTMAQFELSYFYT INFVRFDGSMHPVIHDKLKRFKLHTCETFLNKLAIPNKGLSSWLT SGEYKRLGYIAEDAG - IRIPFVCKEIP NVSTSILSQVSVRQARVMCQFELPIFYTAHLVRYDGAMHPAIHNALKRFKLRDSEINLNTLAIPTSSSKTWYT GKCYKQLVGRLDIPDEIKIPFYTKEVP SVSTNI LSRCTVKQARVALNFELTPFFTTNF IKYDGSMHPEIHRLLKSYKLRESEMLLTKIAIPYQFVGQWVTVKEYERQG IHLNCPEKVKIPFYVHGIP GVST SLIGNCTVRQVKTMQQFELSPFF IQNFVAHDGSMHPVIHDILKKYKLRDCMT PLCDQSIPYRASSTWLSVSEYERLGVALEIPKQVKIAFHIKEIP NVSTSILGNVTVKQARTMSVFEITPFYT SQVVRYDGSMHPQVHALLKRFKLRDSEIVLNKLAIPHRGVNAWLTASEYARLGANVEDRRDVRIPFMCRDIP

EHLQEKLWET IQQYKGDAGFGRCTSANACK IAYTLSVSPFMI PAT INK IDALMAEERQKMEYFQTVTANTCT ISNF SISSIGDMIRSRYSTNHSRENLQK ETLHERIWQAVETHKSDAGFGRICSSSACK IAYTLQTDIHS I PRT IKI IDALLEQERTKQAHFRAMT SQSCSS SNF SLSSIT SAIRSKYAKDHTEENIGV DKLHENVWA IVEKFKCDAGIGRMT SAQASKVAYTLETDIHSVQRTILI IDQLLEREMQKQSHFEMVTNQSCS SGMLSLQTMMNAIQSRYAKNHTAGNIEI DSLHEE IWHIVVAHKGDSGIGRLT SVQAAKVVYTLQTDVHSIART LACINRR IADEQMKQSHFEAAT GRAF SFTNYS IQS IFDTLKANYATKHTKENIAV EKVPEQIWDVMVKF SSDAGFGRMT SAAACKVAYTLQTDIHSIQRTVQIIDRLLENEMKKRNHFNLVVNQSCS SHFMSLSSIMASLRAHYAKNHTGQNIEI DKLYEMLWDTVCKYKNDAGFGSVKSVNATKISYTLSTDPTAI PRTLAILDHLLSEEMTKKSHFDTIGSAVTGYS - FSLAGIADGFRKRYLKDYTQHNIAV PKLHEMLWETVVKYKDVCLFPSIRASSISKIAYTLRTDLFAIPRTLILVERLLEEERVKQSQFRSLIDEGCSS-MFSIVNLTNTLRARYAKDYTAENIQK EKLHLDMWDVIVKFKGDAGFGRLSSASASKVAYTLQTDVNSIQRTVTIIDTLIAEERRKQEYFKTVT SNCVSSSNFSLQSITNAIKSRMMKDHTCENISV

644

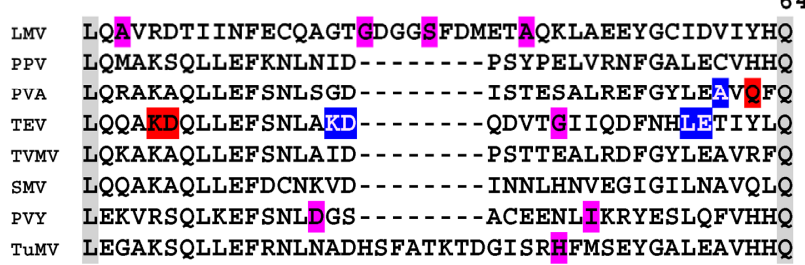

Fig. 3. Cylindrical inclusion (CI) protein sequence alignment of model potyviruses (numbering according to TuMV CI sequence). Conserved amino acids are colored in gray and helicase domains determined according to Fairman-Williams and associates (2010) are indicated in the red boxes. Amino acid positions whose mutation affects virus replication are highlighted in red, virus movement in green, both replication and movement in yellow, virulence against plant resistance in purple, and permissive amino acid positions whose mutation does not affect the viral cycle in blue. Data on LMV refer to Krause-Sakate and associates (2005), Abdul-Razzak, and associates (2009), and personal data (M. Sorel and L. Svanella, unpublished). Data on PPV refer to Fernández and associates (1997) and Gómez de Cedrón and associates (2006). Data on PVA refer to Kekarainen and associates (2002). Data on TEV refer to Chu and associates (1997) and Carrington and associates (1998). Data on TVMV refer to Klein and associates (1994). Data on SMV refer to Zhang and associates (2009) and Seo and associates (2009). Data on PVY refers to Faurez and associates (2012). Data on TuMV refer to Jenner and associates (2000, 2002) and Fujiwara and associates (2011). Sequences were retrieved from GenBank: accession numbers 21492611 (PVA), 9629179 (TVMV), 9790340 (TEV), 9627728 (PVY), 9626508 (PPV), 20153339 (LMV), 56407093 (TuMV), and 12018225 (SMV). 
membrane-associated cation-binding protein 1 (PCaP1) (Vijayapalani et al. 2012). Furthermore, the PD localization of CI in N. benthamiana leaf cells was shown to be modulated by its interaction with P3N-PIPO (Wei et al. 2010b). Altogether, ultrastructural studies and subcellular localization data suggest that the potyvirus CI is involved in cell-to-cell movement, likely through the formation of conical structures anchored to and extending through PD. Furthermore, CI protein was also detected in the phloem of infected plants and in the companion cells in different studies (Lawson et al. 1971; Otulak and Garbaczewska 2012; YanHong et al. 2009), suggesting a potential role in long-distance movement of the virus.

Genetic evidence of the role of the CI protein in movement. Alanine-scanning mutagenesis experiments performed on TEV CI (Carrington et al. 1998) together with point mutation analyses of PPV CI (Gómez de Cedrón et al. 2006) in the N-terminal 177-aa CI self-interaction domain (López et al. 2001), identified mutations that did not disturb viral replication but delayed or blocked cell-to-cell movement. The alanine replacement of Asp3 and Asp4 (DD3,4AA mutation) drastically impaired cellto-cell spread of both TEV and PPV (Fig. 3). Mutations to alanines of Lys100, Arg 101 (KR100,101AA) and Lys 101, Lys 102 (KK101,102AA), respectively, for TEV and PPV affected cell-to-cell movement in a host-specific manner in the case of PPV. Both double mutations (DD3,4AA and KK101,102AA) significantly reduced the self-interaction strength of PPV CI in the $\mathrm{Y} 2 \mathrm{H}$ system. Furthermore, the defect in cell-to-cell movement of TEV with CI mutations DD3,4AA or KK101,102AA was linked to the absence of PD-associated structures in the presence of P3N-PIPO, even though P3N-PIPO-CI interaction still occurred (Wei et al. 2010b). These results argue that CI structures are necessary for cell-to-cell movement of the virus. Nevertheless, the PPV CI self-interaction evident in planta by BiFC (Zilian and Maiss 2011) occurred in small aggregates located close to the plasma membrane, possibly in PD, even in the absence of a P3N-PIPO partner.

In addition to the cell-to-cell movement-defective mutants with amino acid changes in the N-terminus of CI, Carrington and associates (1998) designed TEV mutants with substitutions in the C-terminal part of the protein (EE502,503AA, KD512,513AA, and KD602,603AA) (Fig. 3). These mutants proved to be able to establish multicellular infection foci by functional cell-to-cell movement despite a low replication level for two of them. However, long-distance movement seemed to be impaired, because no systemic infection was detected. This suggests an involvement of the CI protein in the long-distance movement of the virus. Thus, it is of interest to investigate the possible role of CI in phloem loading and unloading, and to assess whether the functionally unknown C-terminal part of the protein participates in this presumed function. It would also be of interest to map the interaction domain of CI with P3N-PIPO and to determine whether long-distance movement is dependent on this interaction as well.

All these data point toward an essential role of $\mathrm{CI}$ in the virus movement as a part of a multiprotein "movement complex".

Cell-to-cell movement complex for potyvirus infection. The cone-shaped structures formed by CI and anchored at PD early in the infection by P3N-PIPO-CI interaction were also shown to contain CP and viral RNA (Roberts et al. 1998; RodríguezCerezo et al. 1997; Wei et al. 2010b). Furthermore, different studies revealed interactions between CI and CP proteins (Langenberg 1991; Zilian and Maiss 2011), and the CI protein was shown to be associated with entire virus particles for PVA, PVY, and TEV (Gabrenaite-Verkhovskaya et al. 2008; Langenberg and Purcifull 1989). BiFC evidence even located the PPV CI-CP interaction in aggregates in close proximity to the plasma membrane. The CI of PVA was demonstrated to interact with HC-Pro as well. Unlike the CI, CP, HC-Pro, and P3N-PIPO are able to increase the SEL of PD to promote their own cell-to-cell movement (Rojas et al. 1997; Vijayapalani et al. 2012). Therewith, genetic evidence shows that the P3NPIPO and CP are essential for virus cell-to-cell movement (Wen and Hajimorad 2010; Dolja et al. 1994, 1995) while evidence exists for the involvement in this process of the HC-Pro protein, which could as well be able to move autonomously from cell to cell and long distance in order to fulfill its silencing suppression function (Kasschau and Carrington 2001).

In light of these experimental data, one can conceive a model in which CI self-interacts to form pinwheel inclusions anchored to the PD via CI-P3N-PIPO interaction. This selfinteraction seems to be dependent on the N-terminal part of the CI whose mutations abolish the cell-to-cell movement. Those cone-shaped CI structures cross the PD, making a tunnel to facilitate the movement of the virus. Their interaction with $\mathrm{CP}$ and the viral RNA could help the recruiting and concentration of viral movement forms in the PD, analogously to a funnel. Recent data on TuMV infection demonstrated that intracellular movement of the $6 \mathrm{~K} 2$ vesicles was necessary for cell-to-cell movement of the virus and that both early and late secretory pathways were required for TuMV intercellular movement (Agbeci et al. 2013). The authors hypothesize that the secretory pathway would be required for sorting membrane-associated viral RNA protein complexes to PDs. Hence, the targeting of the virus to PD might be operated via vesicle recruitment to PD by interaction between spike-like CI associated with vesicles and pinwheel CI associated with PDs.

This suggests either docking of these vesicles at PD for unloading of the virion or viral RNA-CP complex to the adjacent cell, or movement of the vesicles themselves from cell to cell.

The movement of $6 \mathrm{~K} 2$ vesicles has been described to occur from cytoplasm toward viral factory and back to the cytoplasm (Grangeon et al. 2012), suggesting a recycling of the vesicles. This could explain the existence of two types of vesicles observed in infected cells: electron-dense and electron-translucide vesicles (Calder and Ingerfeld 1990; Grangeon et al. 2012), corresponding to vesicles targeted to PD or back to the perinuclear structure. If vesicles are recycled back to the viral factory, cell-to-cell movement of the virus would need their unloading at the PD vicinity. Most of the positive-sense RNA viruses induce replication vesicles, emerging from different host cell compartments. These vesicles are interconnected and, in most of the cases, are linked to the cytoplasm by neck-like opening allowing the export of the viral RNA (den Boon and Ahlquist 2010). No such opening has been observed to date in $6 \mathrm{~K} 2$ vesicles, implying that the hypothetical export would be driven by protein transport. These proteins would be associated with the vesicle membrane by transmembrane domains or amphipathic helixes, as detected in the $\mathrm{N}$-terminal region of $2 \mathrm{C}$ protein of picornaviruses.

Therewith, the transfer through PD might be an active process, utilizing the energy of ATPase activity of CI. In fact, ATPase activity was demonstrated in PD of maize infected by MDMV (Chen et al. 1994), demonstrating that the CI helicase domain could be active even in PD. Consequently, one can hypothesize that the CI RNA helicase, beside replication, could be involved as a chaperone or maturase that facilitates a correct RNA folding or be involved in the rearrangement of RNA-protein interactions, as suggested by Schwer (2001) and Linder (2004), to form functional viral movement ribonucleic acid-protein complexes (RNPs). Our knowledge here is limited by the inability to uncouple replication and movement in order to study the virus cell-to-cell movement in the absence of helicase activity. On the other hand, in contrast to the enhancement in translatability of virus particles of the potex- 
virus Potato virus $X$ by interaction of the MP with RNA helicase activity TGBp1 (Atabekov et al. 2000), the attachment of CI to PVA virions appears to reinforce particle integrity and to reduce the translation efficiency (Gabrenaite-Verkhovskaya et al. 2008). Thus, it is suggested that detachment of CI from particles after transport through the PD may be required to initiate a new infection.

Although the replication and movement functions of the CI protein are discussed separately in the present review, these two processes could act in a coordinated way. Indeed, Tilsner and Oparka (2012) recently proposed a model for coupling of movement and replication of viruses. Their review gathers multiple examples of viral MPs associated with vesicle replication complexes (VRCs) and shows how this localization is correlated with viral cell-to-cell movement. In the case of potyviruses, the CI protein is the top candidate for this link between replication and movement: the inclusions could provide an ordered structure for anchoring the VRC and targeting it to PD.

\section{CI and host resistance.}

Plant viruses are difficult to combat and the use of cultivars that are genetically resistant to viruses has become a critical factor for sustainable agriculture (Elena et al. 2011). Resistance to viruses can be determined by defensive reactions of the plant in response to the recognition of molecular patterns common to different pathogens as dsRNA, which induces antiviral RNA silencing; defense mediated by dominant resistance $(R)$ genes that are elicited by specific factors of the virus; and by the absence or lack of functionality of host factors required for the viral infection, which are governed by recessive resistance genes (Pallas and García 2011). Unfortunately, the use of resistance genes for crop protection suffers from the emergence of adapted resistance-breaking virus populations, as a consequence of the ability of the virus to evolve, favored by the selective pressure.

$R$-gene-mediated recognition of virus elicitors is accompanied by hypersensitive response (HR) or extreme resistance (ExR). In the first case, HR is characterized by the appearance of macroscopic necrotic lesions at the site of inoculation (local lesions) whereas, in ExR, plants remain symptomless and virus accumulation is undetectable even in the inoculated leaf. Sometimes, the virus can escape the HR in the inoculated leaf and move to the upper leaves, where the systemic hypersensitive response takes place, which can be lethal, leading to the death of the plant. The $R$ genes involved in these reactions code for products that interact directly or indirectly with corresponding viral elements that are known as avirulence (Avr) factors (Dangl et al. 2013; Flor 1971). Any protein of the infecting virus can be the particular Avr specifically recognized by the $R$ gene (Culver 1997). In many cases, it has been possible to map the precise amino acids in viral proteins that determine the recognition, and mutations in these residues allow the virus to recover virulence. Similarly, in the cases of recessive resistance derived from the inability of the resistant plant to provide a functional element required for the infection process, the virus can be adapted by mutations in a viral factor that facilitates a productive interaction with the defective host factor or even the escape from its requirement. The potyvirus CI protein was shown to be involved in the elicitation of defensive responses mediated by $R$ genes and in presumed interactions with host factors determining recessive resistance. Mutations in the CI coding region were shown to allow potyviruses to break both kinds of resistance in several plant-potyvirus pathosystems. Moreover, CI has been shown to be an important determinant of the symptoms caused by potyviruses in productive infections.
CI: a resistance-eliciting and resistance-breaking determinant. The Avr determinant may be multifaceted for some resistance traits, as illustrated by the thoroughly studied pathosystem involving Soybean mosaic virus (SMV) and soybean, where three distinct $R$ genes $(R s v 1, R s v 3$, and $R s v 4)$ conferring dominant resistance to different strains of SMV were reported (Hayes et al. 2004; ShagaiMaroof et al. 2010; Suh et al. 2011). Several studies suggest that different disease responses on soybean cultivars result from interactions among these three $R$ genes and viral pathogenic determinants. The molecular determinants in SMV for $R s v$-resistance breaking have been characterized to various extents (Chowda-Reddy et al. 2011; Hajimorad et al. 2008; Khatabi et al. 2012; Seo et al. 2009, 2011; Wen et al. 2013; Zhang et al. 2009). In particular, determinants for virulence on Rsv3 were mapped to the CI protein (Seo et al. 2009; Zhang et al. 2009). By using chimeras between avirulent and virulent SMV isolates, the authors demonstrated that both the $\mathrm{N}$-terminal and $\mathrm{C}$-terminal parts of $\mathrm{CI}$ are required for $R s v 3$-mediated resistance breaking (Seo et al. 2009; Zhang et al. 2009) and revealed the key role played by amino acids heterogeneities D/A37 and R/K589 of CI for gain or loss of elicitor function (Fig. 3). In addition, Chowda-Reddy and coworkers (2011) intended to demonstrate the possible interactions between viral Avr factors involved in the three $R s v$ resistances. The authors showed that appropriate CI sequences are required for gain of virulence on $R s v 1$ and $R s v 3$ genotype soybean, although P3 also played an essential role in virulence determination on these two resistance loci as well as on Rsv4confered resistance. This study, consequently, emphasizes the importance of the genetic background of the virus in the overcoming process and its complexity in the case of pyramided resistances.

CI was also shown to be an Avr factor for several other potyviruses. Another case of P3-CI co-involvement in virulence in resistant plants was evidenced for the TuMV-Brassica napus pathosystem (Jenner 2002), with a particular P3 sequence enabling the virus to overpass the TuRB04-mediated ExR, epistatic to the TuRB05-mediated HR, which could be overcome by TuMV carrying an M589T mutation in the CI C-terminal region (Fig. 3). Another B. napus resistance against TuMV, conferred by TuRBO1, is overcome by mutations in the CI protein at positions 335 ( $\mathrm{S}$ to $\mathrm{N}$ ) and 630 (H to R) (Fig. 3) (Jenner et al. 2000), as well as the resistance conferred by the gene Rnt1 in B. rapa, which is overcome by the V600E mutation in the CI C-terminal region (Fujiwara et al. 2011). Despite the fact that they share a common virulence determinant, the TuRB05 $R$ gene is considered to be different from TuRBO1 based on the resistance phenotype. In fact TuRBO1 triggers ExR while TuRB05 triggers HR, and TuMV variants able to infect TuRB05-resistant plants do not infect TuRBO1 plants. On the other hand, TuRBO1 and Rtnl loci are mapped on the same chromosomal region and the authors do not conclude whether they are different alleles of the same gene or two different but closely located $R$ genes.

Whereas dominant $R$ genes are the most usual source of resistance against bacteria and fungi, recessive resistance is frequently found for plant viruses (Truniger and Aranda 2009). Since the molecular cloning of the first recessive resistance gene against a plant potyvirus 10 years ago (Nicaise et al. 2003; Ruffel et al. 2002), all studies aiming at the characterization of recessive resistance from a range of plant species have, thus far, only identified genes coding for translation initiation factors eIF4E, eIF4G, and their isoforms (Truniger and Aranda 2009; Wang and Krishnaswamy 2012).

Although the majority of eIF4E-resistance breakdowns have been associated with mutations in the central region of VPg (Charron et al. 2008; Moury et al. 2004; Yeam et al. 2007), 
amino acid changes in two other potyviral proteins were recently described to be involved in the breakdown of eIF4Emediated resistances: the CI and P1 proteins in the lettuceLMV (Abdul-Razzak et al. 2009) and pea-Clover yellow vein virus (Nakahara et al. 2010) pathosystems, respectively. In particular, site-directed mutagenesis in LMV CI pinpointed a key role of a threonine at position 621 in the virulence (AbdulRazzak et al. 2009). Interactions between VPg and HC-Pro of LMV and between LMV VPg and lettuce eIF4E were demonstrated in vitro (German-Retana et al. 2008; RoudetTavert et al. 2007). Recently, both the central domain of LMV VPg and the C-terminal domain of LMV CI (amino acids 372 to 643) were shown to be involved in binding to lettuce eIF4E in vitro and in planta (Tavert-Roudet et al. 2012). HC-Pro of another potyvirus, PVA, was also recently demonstrated to be an interaction partner of eIF4E (Ala-Poikela et al. 2011), suggesting that the step of viral infection in which eIF4E is involved could also be either facilitated or regulated by HCPro (and host proteins interacting with it).

Therefore, the $\mathrm{C}$ terminus of LMV CI could be involved in a complex network of viral and cellular protein interactions, involving (in addition to the CI protein) VPg, eIF4E, and, possibly, HC-Pro and the translation initiation factor eIF4G, shown to be required for LMV infection in A. thaliana (Nicaise et al. 2007). Such interactions should be crucial for eIF4E recruitment and could play important roles in different processes in the viral infection. The VPg of potyviruses is expected to contribute to both genome replication (Puustinen and Mäkinen 2004) and translation (Eskelin et al. 2011), which are mutually exclusive processes. In this context, mutually exclusive interactions of VPg with CI or cellular eIF4E might conceivably be associated with replication and translation, respectively. In such a scenario, eIF4E-mediated resistance would be hypothesized to interfere with replication or translation either by a defect on VPg-eIF4E interactions (overcome by mutations in $\mathrm{VPg}$ ) or by interference of CI in this interaction (overcome either by VPg or CI mutations); because mutations in P1 can also suppress eIF4E-based resistance, P1 would be expected to be involved in any of these interactions. In an alternative scenario, P1, HC-Pro, CI, VPg, eIF4E, and eIF4G could be forming a large multicomponent complex, whose structure would not be necessarily static and that probably would be nucleated by VPg and involved in viral replication. As explained above, there is abundant evidence of a close relationship between replication complexes and viral movement (Tilsner and Oparka 2012); thus, it is not surprising that eIF4E-based resistance could act at the level of virus cell-to-cell movement as well, as has also been postulated for some pea and lettuce resistance genes (Gao et al. 2004; German-Retana et al. 2003). In particular, in lettuce, the $m o l^{2}$ allele at the Ls-eIF4E locus restricts the intercellular movement of the avirulent isolate LMV-0 and affects its loading and unloading from the phloem (GermanRetana et al. 2003). Therefore, the eIF4E-LMV CI interaction could contribute somehow to the cell-to-cell and long-distance movement process. More effort, however, is still needed to understand this network and the underlying function or functions that are associated with the viral and host protein interactions involved.

In any case, as shown above, the C-terminal part of the CI protein carries virulence determinants toward numerous plant resistances for different potyviruses. Interestingly, this region, unlike to the central helicase domain, shows high sequence variability among Potyvirus spp. This variability could be interpreted as the CI C-terminal region being involved in specific interactions with host factors and adaptation to new hosts.

It is also interesting to remark that CI is not only a direct actor in resistance breakdown and possibly in adaptation to new hosts. Moreover, it has been observed that exchanging the CI cistron of a PVY isolate by another one could confer to the resulting chimera an enhanced capacity to evolve toward breaking of eIF4E-mediated resistance (Montarry et al. 2011; E. Redondo, personal communication). The mechanistic basis of this enhancement is unknown but it does not involve an increase in the global mutation rate of the virus (Montarry et al. 2011).

CI: a viral pathogenesis determinant. CI protein was shown to be a symptom determinant in B. rapa carrying the Rntl locus, determining the ability of TuMV to cause leaf malformation, necrosis, or mild mosaic, depending on the Rntl allele and the TuMV isolate (Fujiwara et al. 2011). In parallel, an S/N heterogeneity at position 7 of SMV CI was shown to be involved in symptom determinism in susceptible soybean cultivars (Zhang et al. 2009). The TEV CI-6K2 region is involved in wilting symptoms induced on Tabasco pepper, pointing out the possible role of G619 of the C-terminal part of the CI, and the additional involvement of the P3 protein (Chu et al. 1997). Indeed, replacing both the $\mathrm{P} 3-\mathrm{C}$-terminus (PIPO sequence not included) and CI C-terminus $6 \mathrm{~K} 2-\mathrm{VPg} \mathrm{N}$-terminus fragments from a wilting TEV isolate with the corresponding fragments of a mosaic TEV isolate abolishes the wilting response. Similarly, a necrotic response of lettuce to the LMV-AF199 isolate was shown to depend on P1 N-terminus and CI C-terminus sequences (Krause-Sakate et al. 2005). It was hypothesized that RNA sequence rather than protein was involved, because transient expression of each protein alone or in combination did not trigger necrosis. Involvement of each region alone could not be tested because chimeras exchanging only the P1 N-terminus or CI C-terminus sequences between LMV-E and AF199 were not infectious. Comparable results were obtained when studying PVY symptom determinants in tobacco plants (Faurez and Baldwin 2012). In fact, two regions of the PVY genome, independent from HC-Pro, were able to induce necrotic symptoms: CI C-terminus-VPg N-terminus (R1) and VPg Cterminus-NIapro N-terminus (R3), while the in-between region (R2) VPg-central had no effect. Both R1 and R3 regions had to originate from a non-necrotic isolate to prevent necrosis from occurring. However, clones exchanging both R1 and R2 regions were not infectious. These findings emphasize the possible role of CI in symptom determinism and also the fact that chimeric viruses exchanging parts of viral proteins may not be infectious. In addition, chimeric viruses with foreign CI sequences can cause new types of symptoms, different from those caused by the parental viruses. This is the case of some LMV chimeras which provoke vein curving on susceptible lettuce (Redondo et al. 2001).

Bilgin and coworkers (2003) demonstrated that the helicase domains of TEV CI as well as the TMV P50 helicase were able to interact with the $\mathrm{P} 58^{\mathrm{IPK}}$ protein from $N$. benthamiana and $A$. thaliana in a $\mathrm{Y} 2 \mathrm{H}$ system and in planta. This factor proved to facilitate virus infection, because loss of P58 ${ }^{\mathrm{IPK}}$ in silenced or knockout plants led to reduced viral accumulation. Furthermore, viral infection of $\mathrm{P} 8^{\mathrm{IPK}}$-silenced $N$. benthamiana and knockout Arabidopsis led to host death. In animal cells, the P58 ${ }^{\mathrm{IPK}}$ ortholog is an ER factor involved in the attenuation of the unfolded protein response upon ER stress and as a cellular inhibitor of the host defense that interferes with virus-induced apoptosis and inflammation to improve host survival, allowing further virus accumulation (Goodman et al. 2009). In plants, $\mathrm{P} 58^{\mathrm{IPK}}$ could endorse a similar role, because $\mathrm{P} 58^{\mathrm{IPK}}$-defective mutants were more sensitive to virus-induced cell death. No data are available about the way P58 ${ }^{\mathrm{IPK}}$ is activated upon viral infection but one can hypothesize that the interaction with the viral helicase, which carries ATPase activity, could induce structural changes that activate P58 ${ }^{\mathrm{IPK}}$. The 
interaction of $\mathrm{CI}$ with $\mathrm{P} 58^{\mathrm{IPK}}$ would then interfere with the ability of the plant to induce stress-associated necrosis, facilitating viral infection.

In contrast, downregulation of the psaK gene, which codes for the PSI-K protein, leads to higher PPV accumulation, and the interaction of PPV CI with PSI-K induces the degradation of this chloroplastic protein (Jiménez et al. 2006). These results prompted the suggestion that PSI-K is involved in a host defensive response and CI contributes to counteract this defense. These possible connections of CI with host defensive pathways might be related to the involvement of CI in symptom determinism. In fact, the interaction of CI with P58 $8^{\mathrm{IPK}}$ might be involved in the attenuation of the plant symptoms by inhibiting the plant defenses, while the inhibition of the host defenses by degradation of PSI-K upon CI interaction would interfere with the photosynthetic system and induce symptoms such as mosaic.

\section{CONCLUSION}

Taken together, data from this review, including genetic, biochemical, cellular, and ultrastructural studies, highly suggest that the CI protein of the family Potyviridae is involved in a large network of interactions with viral and cellular proteins. Therefore, the CI protein can be envisioned as a multifunctional scaffolding protein involved in crucial steps of the viral infection (replication, translation, and movement of the virus) and in elicitation and overcoming of plant defenses. Furthermore, many of the CI functions, or consequences of them, are probably transient, and the different subcellular localizations of the CI protein that have been observed (PD-connected and cytosolic pinwheels, ER- and chloroplast-associated membrane vesicles, and so on) could be the consequence of this pluri-functionality. Here, we propose a preliminary working model to integrate the fate of the CI protein during viral infection (Fig. 4).

In newly infected cells, the CI protein detaches from the virion to allow decapsidation and viral RNA translation in the cytoplasm of infected cells. A pool of CI is incorporated into pinwheel-shaped inclusions and associated with the PDs through interactions with P3N-PIPO. These structures allow recruitment of RNP or virions to $\mathrm{PD}$ and movement to the adjacent cell via interaction with $\mathrm{CP}$ and viral RNA. Simultaneously, a pool of CI proteins is recruited to the $6 \mathrm{~K} 2$-induced vesicles, thanks to intermediate cleavage form 6K2-CI. The expression of $6 \mathrm{~K} 2$ protein induces a disorganization of the early secretory pathway, giving birth to a large globular perinuclear structure amalgamating ER, Golgi, COPI, and COPII coatomers and chloroplasts, probably by inhibition of the protein secretion. This structure, considered as a "viral factory", is the place of extensive genome translation and replication. In this viral factory, the CI could play a role in switching from

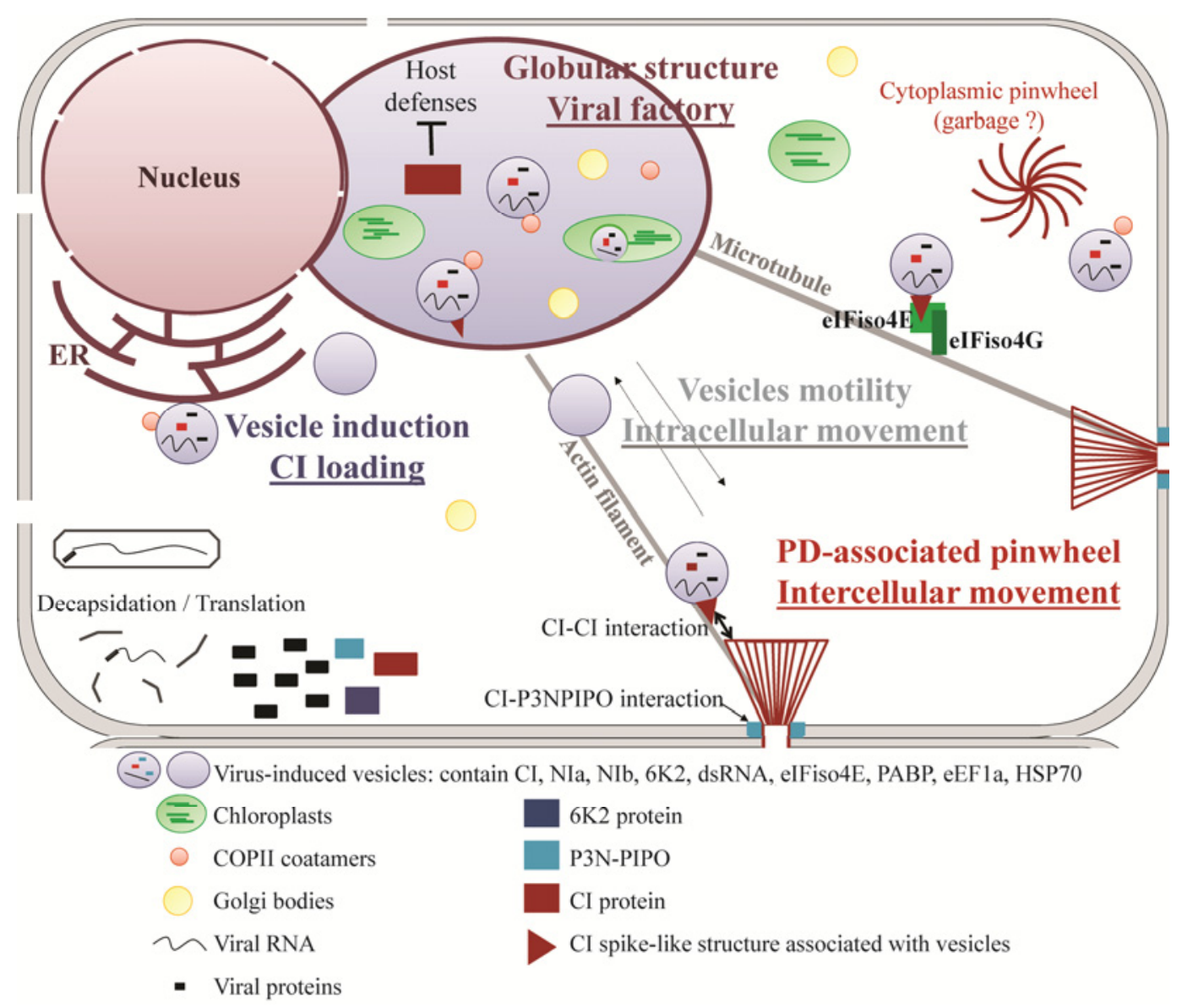

Fig. 4. Integrative model of the different functions of cylindrical inclusion $(\mathrm{CI})$ in the potyviral cycle. The CI is loaded into the $6 \mathrm{~K} 2$-induced vesicles via its fusion with $6 \mathrm{~K} 2$. Those vesicles are part of a large perinuclear globular structure where the CI is involved in viral translation and replication, as well as inhibition of host defenses by interactions with host partners (P58 $8^{\mathrm{IPK}}$, PSI-K). Another pool of CI proteins is recruited to the plasmodesmata (PD) by interaction with P3N-PIPO, where it assembles into pinwheel structures facilitating viral intercellular movement to adjacent cells. The $6 \mathrm{~K} 2$ vesicles associated with CI spike-like structures are proposed to target the viral content to the PD for further movement. This targeting is operated either via actin filament through CI-CI interaction between spike-like structures and pinwheels or via the microtubules interacting with the CI-eIF(iso)4E-eIF(iso)4G complex. Later in infection, pinwheels retreat in the cytoplasm, probably as a garbage form. 
translation to replication in a model where VPg-eIF4E and $\mathrm{VPg}-\mathrm{CI}$ interactions are mutually exclusive. Alternatively, the CI helicase could act as a maturase and facilitate the switch between translation and replication by RNA-protein interaction rearrangement.

In addition to replication and translation, the CI would interfere with the host defense machinery by its interactions with the host ER P58 ${ }^{\mathrm{IPK}}$ protein, probably influencing symptom determinism in the plant. Similarly, the CI is likely to interact with PSI-K protein within the abnormal amoeboid-shaped chloroplasts observed by Wei and associates (2010a), whose extrusions encircle vesicles. This invagination is thought to be the preferential organelle for robust virus replication. Hence, in chloroplasts, the CI protein might participate to the RNA replication via its helicase activity but also contribute to the host defense neutralization by degradation of PSI-K. This CIPSI-K interaction is also likely to induce symptoms such as mosaic by disorganization of the host photosystem.

The perinuclear viral factory is connected to the host secretory pathway, and $6 \mathrm{~K} 2$ vesicles emerge from it and move intracellularly following transvacuolar actin strands. These vesicles containing viral RNA could provide a protective environment for virion assembly. When the vesicles reach the PD-associated pinwheels, interaction between the CI spike-like structures at the surface of the $6 \mathrm{~K} 2$ vesicles and the pinwheel CI provides docking of the vesicles and movement to the adjacent cell. This would occur either by direct transfer of the vesicles or by unloading of the vesicle content through the PD, powered by the energy provided by ATPase activity of the CI protein. "Empty" vesicles are then recycled back to the viral factory by actin-dependent intracellular movement. At later times of infection, when further transport is not required, the pinwheels are detached from the membrane and become garbage in the cytoplasm. An alternative hypothesis states that the interaction of CI with eIF4E which, in turn, interacts with eIF4G would facilitate intracellular movement of those vesicles or a viral movement complex via eIF4G association with microtubules.

As previously mentioned, this model is a working base, gathering information collected on different pathosystems. It is of importance to assess whether the perinuclear globular structure described in TuMV-infected cells is a common feature of Potyviridae infection or specific to this species and to the precise possible compartmentalization of replication and translation within this structure. In the future, correlative microscopy should be a useful tool to localize proteins or protein complexes in subcellular compartments, opening the way to new findings.

\section{ACKNOWLEDGMENTS}

We thank A. G. Abbott for his help with the English in the manuscript.

\section{LITERATURE CITED}

Abdul-Razzak, A., Guiraud, T., Peypelut, M., Walter, J., Houvenaghel, M.C., Candresse, T., Le Gall, O., and German-Retana, S. 2009. Involvement of the cylindrical inclusion (CI) protein in the overcoming of an eIF4E-mediated resistance against Lettuce mosaic potyvirus. Mol. Plant Pathol. 10:109-113.

Adams, M. J., Antoniw, J. F., and Fauquet, C. M. 2005. Molecular criteria for genus and species discrimination within the family Potyviridae. Arch. Virol. 150:459-479.

Adams, M. J., King, A. M., Lefkowitz, E., and Carstens, E. B. 2011. Part II: The viruses-family Potyviridae. Pages 1069-1090 in: Virus Taxonomy-Ninth Rep. Int. Committee on Taxonomy of Viruses, Elsevier, San Diego, CA, U.S.A.

Agbeci, M., Grangeon, R., Nelson, R. S., Zheng, H., and Laliberté, J.-F. 2013. Contribution of host intracellular transport machineries to inter- cellular movement of Turnip mosaic virus. PLoS Pathog. 9:e1003683. Published online.

Ala-Poikela, M., Goytia, E., Haikonen, T., Rajamäki, M.-L., and Valkonen, J. P. T. 2011. Helper component proteinase of the genus Potyvirus is an interaction partner of translation initiation factors eIF(iso)4E and eIF4E and contains a 4E binding motif. J. Virol. 85:6784-6794.

Ammar, E., Rodriguez-Cerezo, E., Shaw, J., and Pirone, T. 1994. Association of virions and coat protein of tobacco vein mottling potyvirus with cylindrical inclusions in tobacco cells. Phytopathology 84:520-524.

Arbatova, J., Lehto, K., Pehu, E., and Pehu, T. 1998. Localization of the $\mathrm{P} 1$ protein of potato $\mathrm{Y}$ potyvirus in association with cytoplasmic inclusion bodies and in the cytoplasm of infected cells. J. Gen. Virol. 79:2319-2323.

Astier S., Albouy J., Maury Y., Robaglia C., and Lecoq H. 2001. Principes de virologie végétale. Page 444 in: Génome, Pouvoir Pathogène, Écologie des Virus. INRA Éditions, Paris.

Atabekov, J. G., Rodionova, N. P., Karpova, O. V, Kozlovsky, S. V, and Poljakov, V. Y. 2000. The movement protein-triggered in situ conversion of Potato virus $X$ virion RNA from a nontranslatable into a translatable form. Virology 271:259-263.

Beauchemin, C., and Laliberté, J.-F. 2007. The poly(A) binding protein is internalized in virus-induced vesicles or redistributed to the nucleolus during Turnip mosaic virus infection. J. Virol. 81:10905-10913.

Bilgin, D. D., Liu, Y., Schiff, M., and Dinesh-Kumar, S. P. 2003. P58 ${ }^{\text {IPK }}$, a plant ortholog of double-stranded RNA-dependent protein kinase pkr inhibitor, functions in viral pathogenesis. Dev. Cell 4:651-661.

Calder, V. L., and Ingerfeld, M. 1990. The roles of the cylindrical inclusion protein of a potyvirus in the induction of vesicles and in cell-to-cell spread. J. Struct. Biol. 105:62-66.

Carrington, J. C., Jensen, P. E., and Schaad, M. C. 1998. Genetic evidence for an essential role for potyvirus CI protein in cell-to-cell movement. Plant J. 14:393-400.

Charron, C., Nicolaï, M., Gallois, J.-L., Robaglia, C., Moury, B., Palloix, A., and Caranta, C. 2008. Natural variation and functional analyses provide evidence for co-evolution between plant eIF4E and potyviral VPg. Plant J. 54:56-68.

Chen, S., Das, P., and Hari, V. 1994. In situ localization of ATPase activity in cells of plants infected by maize dwarf mosaic potyvirus. Arch. Virol 134:433-439.

Choi, I.-R., Stenger, D. C., and French, R. 2000. Multiple interactions among proteins encoded by the mite-transmitted wheat streak mosaic tritimovirus. Virology 267:185-198.

Chowda-Reddy, R. V, Sun, H., Hill, J. H., Poysa, V., and Wang, A. 2011. Simultaneous mutations in multi-viral proteins are required for Soybean mosaic virus to gain virulence on soybean genotypes carrying different $R$ genes. PLoS One 6:e28342. Published online.

Chu, M., Lopez-Moya, J. J., Llave-Correas, C., and Pirone, T. P. 1997. Two separate regions in the genome of the tobacco etch virus contain determinants of the wilting response of tabasco pepper. Mol. PlantMicrobe Interact. 10:472-480.

Chung, B. Y.-W., Miller, W. A., Atkins, J. F., and Firth, A. E. 2008. An overlapping essential gene in the Potyviridae. Proc. Natl. Acad. Sci. U.S.A. 105:5897-5902

Cotton, S., Grangeon, R., Thivierge, K., Mathieu, I., Ide, C., Wei, T., Wang, A., and Laliberté, J.-F. 2009. Turnip mosaic virus RNA replication complex vesicles are mobile, align with microfilaments, and are each derived from a single viral genome. J. Virol. 83:10460-10471.

Culver, J. N. 1997. Viral avirulence genes. Pages 196-219 in: Plant-Microbe Interactions 2 SE-6. G. Stacey and N. Keen, eds. Springer, Dortrecht, The Netherlands.

Dangl, J., Horvath, D., and Staskawicz, B. 2013. Pivoting the plant immune system from dissection to deployment. Science 341:746-751.

David-Ferreira, J., and Borges, M. 1958. Virus na celula vegetal obseracoes ao microscopio electronico I-Virus Y da batateira. Bol. Soc. Broteriana 32:329-332.

den Boon, J. A., and Ahlquist, P. 2010. Organelle-like membrane compartmentalization of positive-strand RNA virus replication factories. Annu. Rev. Microbiol. 64:241-256.

Dolja, V. V, Haldeman, R., Robertson, N. L., Dougherty, W. G., and Carrington, J. C. 1994. Distinct functions of capsid protein in assembly and movement of tobacco etch potyvirus in plants. EMBO (Eur. Mol. Biol. Organ.) J. 13:1482-1491.

Dolja, V. V, Haldeman-Cahill, R., Montgomery, A. E., Vandenbosch, K. A., and Carrington, J. C. 1995. Capsid protein determinants involved in cell-to-cell and long distance movement of tobacco etch potyvirus. Virology 206:1007-1016.

Dougherty, W. G., and Hiebert, E. 1980. Translation of potyvirus RNA in a rabbit reticulocyte lysate: Identification of nuclear inclusion proteins as products of tobacco etch virus RNA translation and cylindrical inclusion protein as a product of the potyvirus genome. Virology 104:174-182. 
Eagles, R. M., Balmori-Melián, E., Beck, D. L., Gardner, R. C., and Forster, R. L. 1994. Characterization of NTPase, RNA-binding and RNA-helicase activities of the cytoplasmic inclusion protein of tamarillo mosaic potyvirus. Eur. J. Biochem. 224:677-684

Edwardson, J., Christie, R., and Ko, N. 1984. Potyvirus cylindrical inclusions-subdivision IV. Phytopathology 74:1111-1114.

Edwardson, J. R. 1966. Cylindrical inclusions in the cytoplasm of leaf cells infected with tobacco etch virus. Science 153:883-884.

Edwardson, J. R. 1974. Some Properties of the Potato Virus Y Group. Institute of Food and Agricultural Sciences, University of Florida, Gainesville, FL, U.S.A.

Edwardson, J. R. 1992. Inclusion bodies. Pages 25-30 in: Potyvirus Taxonomy SE-3. O. Barnett, Jr., ed. Springer, Vienna.

Edwardson, J. R., and Christie, R. G. 1978. Use of virus-induced inclusions in classification and diagnosis. Annu. Rev. Phytopathol. 16:31-55.

Elena, S. F., Bedhomme, S., Carrasco, P., Cuevas, J. M., de la Iglesia, F. Lafforgue, G., Lalić, J., Pròsper, A., Tromas, N., and Zwart, M. P. 2011. The evolutionary genetics of emerging plant RNA viruses. Mol. PlantMicrobe Interact. 24:287-293.

Eskelin, K., Hafrén, A., Rantalainen, K. I., and Mäkinen, K. 2011. Potyviral VPg enhances viral RNA translation and inhibits reporter mRNA translation in planta. J. Virol. 85:9210-9221.

Fairman-Williams, M. E., Guenther, U., and Jankowsky, E. 2010. SF1 and SF2 helicases: Family matters. Curr. Opin. Struct. Biol. 20:313-324.

Faurez, F., and Baldwin, T. 2012. Identification of new Potato virus $Y$ (PVY) molecular determinants for the induction of vein necrosis in tobacco. Mol. Plant Pathol. 13:948-959.

Fernández, A., Laín, S., and García, J. A. 1995. RNA helicase activity of the plum pox potyvirus $\mathrm{Cl}$ protein expressed in Escherichia coli. Mapping of an RNA binding domain. Nucleic Acids Res. 23:1327-1332.

Fernández, A., Guo, H. S., Sáenz, P., Simón-Buela, L., Gómez de Cedrón, M., and García, J. A. 1997. The motif V of plum pox potyvirus CI RNA helicase is involved in NTP hydrolysis and is essential for virus RNA replication. Nucleic Acids Res. 25:4474-4480.

Flor, H. H. 1971. Current status of the gene-for-gene concept. Annu. Rev. Phytopathol. 9:275-296.

Fujiwara, A., Inukai, T., Kim, B. M., and Masuta, C. 2011. Combinations of a host resistance gene and the CI gene of Turnip mosaic virus differentially regulate symptom expression in Brassica rapa cultivars. Arch. Virol. 156:1575-1581.

Gabrenaite-Verkhovskaya, R., Andreev, I. A, Kalinina, N. O., Torrance, L., Taliansky, M. E., and Mäkinen, K. 2008. Cylindrical inclusion protein of Potato virus $A$ is associated with a subpopulation of particles isolated from infected plants. J. Gen. Virol. 89:829-838.

Gao, Z., Eyers, S., Thomas, C., Ellis, N., and Maule, A. 2004. Identification of markers tightly linked to sbm recessive genes for resistance to Pea seed-borne mosaic virus. Theor. Appl. Genet. 109:488-494.

German-Retana, S., Redondo, E., Tavert-Roudet, G., Le Gall, O., and Candresse, T. 2003. Introduction of a NIa proteinase cleavage site between the reporter gene and HC-Pro only partially restores the biological properties of GUS- or GFP-tagged LMV. Virus Res. 98:151-162.

German-Retana, S., Walter, J., Doublet, B., Roudet-Tavert, G., Nicaise, V., Lecampion, C., Houvenaghel, M. C., Robaglia, C., Michon, T., and Le Gall, O. 2008. Mutational analysis of plant cap-binding protein eIF4E reveals key amino acids involved in biochemical functions and potyvirus infection. J. Virol. 82:7601-7612.

Goldbach, R., Wellink, J., Verver, J., Kammen, A., Kasteel, D., and Lent, J. 1994. Adaptation of positive-strand RNA viruses to plants. Arch. Virol. (Suppl.) 9:87-97.

Gómez de Cedrón, M., Osaba, L., López, L., and García, J. A. 2006. Genetic analysis of the function of the Plum pox virus CI RNA helicase in virus movement. Virus Res. 116:136-145.

Goodman, A. G., Fornek, J. L., Medigeshi, G. R., Perrone, L. A., Peng, X., Dyer, M. D., Proll, S. C., Knoblaugh, S. E., Carter, V. S., Korth, M. J., Nelson, J. A., Tumpey, T. M., and Katze, M. G. 2009. P58(IPK): A novel "CIHD" member of the host innate defense response against pathogenic virus infection. PLoS Pathog. 5:e1000438. Published online.

Gorbalenya, E., and Koonin, E. V. 1993. Helicases : Amino acid sequence comparisons relationships and of Med. Curr. 3:419-429.

Grangeon, R., Agbeci, M., Chen, J., Grondin, G., Zheng, H., and Laliberté J.-F. 2012. Impact on the endoplasmic reticulum and Golgi apparatus of Turnip mosaic virus infection. J. Virol. 86:9255-9265.

Graybosch, R., Hellmann, G. M., Shaw, J. G., Rhoads, R. E., and Hunt, A. G. 1989. Expression of a potyvirus non-structural protein in transgenic tobacco. Biochem. Biophys. Res. Commun. 160:425-432.

Hajimorad, M. R., Eggenberger, A. L., and Hill, J. H. 2008. Adaptation of Soybean mosaic virus avirulent chimeras containing P3 sequences from virulent strains to Rsv1-genotype soybeans is mediated by mutations in HC-Pro. Mol. Plant-Microbe Interact. 21:937-946.

Hayes, A., Jeong, S., Gore, M., and Yu, Y. 2004. Recombination within a nucleotide-binding-site/leucine-rich-repeat gene cluster produces new variants conditioning resistance to Soybean mosaic virus in soybeans. Genetics 166:493-503

Hiebert, E., and McDonald, J. G. 1973. Characterization of some proteins associated with viruses in the potato Y group. Virology 56:349-361.

Hiebert, E., Purcifull, D. E., Christie, R. G., and Christie, S. R. 1971. Partial purification of inclusions induced by tobacco etch virus and potato virus Y. Virology 43:638-646.

Jenner, C. 2002. Mutations in Turnip mosaic virus P3 and cylindrical inclusion proteins are separately required to overcome two Brassica napus resistance genes. Virology 300:50-59.

Jenner, C. E., Sánchez, F., Nettleship, S. B., Foster, G. D., Ponz, F., and Walsh, J. A. 2000. The cylindrical inclusion gene of Turnip mosaic virus encodes a pathogenic determinant to the Brassica resistance gene TuRB01. Mol. Plant-Microbe Interact. 13:1102-1108.

Jiménez, I., López, L., Alamillo, J. M., Valli, A., and García, J. A. 2006. Identification of a Plum pox virus CI-interacting protein from chloroplast that has a negative effect in virus infection. Mol. Plant-Microbe Interact. 19:350-358.

Kadaré, G., and Haenni, A. 1997. Virus-encoded RNA helicases. J. Virol. $71: 2583-2590$.

Kasschau, K. D., and Carrington, J. C. 2001. Long-distance movement and replication maintenance functions correlate with silencing suppression activity of potyviral HC-Pro. Virology 285:71-81.

Kekarainen, T., Savilahti, H., and Valkonen, J. P. T. 2002. Functional genomics on Potato virus A: Virus genome-wide map of sites essential for virus propagation. Genome Res. 12:584-594.

Khatabi, B., Fajolu, O., Wen, R.-H., and Hajimorad, M. R. 2012. of North American isolates of Soybean mosaic virus for gain of virulence on Rsv-genotype soybeans with special emphasis on resistance-breaking determinants on. Mol. Plant Pathol. 13:1077-1088.

Klein, P., Klein, R., and Rodriguez-Cerezo, E. 1994. Mutational analysis of the tobacco vein mottling virus genome. Virology 204:759-769.

Krause-Sakate, R., Redondo, E., Richard-Forget, F., Jadão, A. S. Houvenaghel, M.-C., German-Retana, S., Pavan, M. A., Candresse, T., Zerbini, F. M., and Le Gall, O. 2005. Molecular mapping of the viral determinants of systemic wilting induced by a Lettuce mosaic virus (LMV) isolate in some lettuce cultivars. Virus Res. 109:175-180.

Laín, S., Riechmann, J., Martín, M. T., and García, J. A. 1989. Homologous potyvirus and flavivirus proteins belonging to a superfamily of helicase-like proteins. Gene. 82:357-362.

Laín, S., Riechmann, J. L., and Garciá, J. A. 1990. RNA helicase: A novel activity associated with a protein encoded by a positive strand RNA virus. Nucleic Acids Res. 18:7003-7006.

Laín, S., Martín, M. T., Riechmann, J. L., and García, J. A. 1991. Novel catalytic activity associated with positive-strand RNA virus infection: Nucleic acid-stimulated ATPase activity of the plum pox potyvirus helicaselike protein. J. Virol. 65:1-6.

Langenberg, W. G. 1986. Virus protein association with cylindrical inclusions of two viruses that infect wheat. J. Gen. Virol. 67:1161-1168.

Langenberg, W. G. 1991. Cylindrical inclusion bodies of wheat streak mosaic virus and three other potyviruses only self-assemble in mixed infections. J. Gen. Virol. 72:493-497.

Langenberg, W. G. 1993. Structural proteins of three viruses in the potyviridae adhere only to their homologous cylindrical inclusions in mixed infections. J. Struct. Biol. 110:188-195.

Langenberg, W. G., and Purcifull, D. E. 1989. Interactions between pepper ringspot virus and cylindrical inclusions of two potyviruses. J. Ultrastruct. Mol. Struct. Res. 102:53-58.

Lawson, R. H., and Hearon, S. S. 1971. The association of pinwheel inclusions with plasmodesmata. Virology 44:454-456.

Lawson, R. H., Hearon, S. S., and Smith, F. F. 1971. Development of pinwheel inclusions associated with sweet potato russet crack virus. Virology 46:453-463.

Linder, P. 2004. Molecular biology. The life of RNA with proteins. Science 304:694-695.

López, L., Urzainqui, A., Domínguez, E., and García, J. A. 2001. Identification of an N-terminal domain of the plum pox potyvirus CI RNA helicase involved in self-interaction in a yeast two-hybrid system. J. Gen. Virol. 82:677-686.

Maiti, I. B., Murphy, J. F., Shaw, J. G., and Hunt, A. G. 1993. Plants that express a potyvirus proteinase gene are resistant to virus infection Proc. Natl. Acad. Sci. U.S.A. 90:6110-6114.

Merits, A., Rajamäki, M.-L., Lindholm, P., Runeberg-Roos, P., Kekarainen, T., Puustinen, P., Mäkeläinen, K., Valkonen, J. P. T., and Saarma, M. 2002. Proteolytic processing of potyviral proteins and polyprotein processing intermediates in insect and plant cells. J. Gen. Virol. 83:1211-1221.

Montarry, J., Doumayrou, J., Simon, V., and Moury, B. 2011. Genetic background matters : A plant-virus gene-for-gene interaction is strongly influenced by genetic contexts. Mol. Plant Pathol. 12:911-920. 
Moury, B., Morel, C., Johansen, E., Guilbaud, L., Souche, S., Ayme, V., Caranta, C., Palloix, A., and Jacquemond, M. 2004. Mutations in Potato virus $Y$ genome-linked protein determine virulence toward recessive resistances in Capsicum annuum and Lycopersicon hirsutum. Mol. Plant-Microbe Interact. 17:322-329.

Nakahara, K. S., Shimada, R., Choi, S.-H., Yamamoto, H., Shao, J., and Uyeda, I. 2010. Involvement of the P1 cistron in overcoming eIF4Emediated recessive resistance against Clover yellow vein virus in pea. Mol. Plant-Microbe Interact. 23:1460-1469.

Nicaise, V., German-Retana, S., Sanjua, R., Dubrana, M., Mazier, M., Maisonneuve, B., Candresse, T., Caranta, C., and Legall, O. 2003. The eukaryotic translation initiation factor $4 \mathrm{E}$ controls lettuce susceptibility to the potyvirus Lettuce mosaic virus. Plant Physiol. 132:1272-1282.

Nicaise, V., Gallois, J.-L., Chafiai, F., Allen, L. M., Schurdi-Levraud, V., Browning, K. S., Candresse, T., Caranta, C., Le Gall, O., and GermanRetana, S. 2007. Coordinated and selective recruitment of eIF4E and eIF4G factors for potyvirus infection in Arabidopsis thaliana. FEBS (Fed. Eur. Biochem. Soc.) Lett. 581:1041-1046.

Otulak, K., and Garbaczewska, G. 2012. Cytopathological Potato virus $Y$ structures during solanaceous plants infection. Micron 43:839-850.

Pallas, V., and García, J. A. 2011. How do plant viruses induce disease? Interactions and interference with host components. J. Gen. Virol. 92:2691-2705.

Purcifull, D. E., Hiebert, E., and McDonald, J. G. 1973. Immunochemical specificity of cytoplasmic inclusions induced by viruses in the potato $\mathrm{Y}$ group. Virology 55:275-279.

Puustinen, P., and Mäkinen, K. 2004. Uridylylation of the potyvirus VPg by viral replicase NIb correlates with the nucleotide binding capacity of VPg. J. Biol. Chem. 279:38103-38110.

Redondo, E., Krause-Sakate, R., Yang, S.-J., Lot, H., Le Gall, O., and Candresse, T. 2001. Lettuce mosaic virus pathogenicity determinants in susceptible and tolerant lettuce cultivars map to different regions of the viral genome. Mol. Plant-Microbe Interact. 14:804-810.

Roberts, I. M., Wang, D., Findlay, K., and Maule, A. J. 1998. Ultrastructural and temporal observations of the potyvirus cylindrical inclusions (Cls) show that the $\mathrm{Cl}$ protein acts transiently in aiding virus movement. Virology 245:173-181.

Rodríguez-Cerezo, E., Ammar, E. D., Pirone, T. P., and Shaw, J. G. 1993. Association of the non-structural P3 viral protein with cylindrical inclusions in potyvirus-infected cells. J. Gen. Virol. 74:1945-1949.

Rodríguez-Cerezo, E., Findlay, K., Shaw, J. G., Lomonossoff, G. P., Qiu, S. G., Linstead, P., Shanks, M., and Risco, C. 1997. The coat and cylindrical inclusion proteins of a potyvirus are associated with connections between plant cells. Virology 236:296-306.

Rojas, M. R., Zerbini, F. M., Allison, R. F., Gilbertson, R. L., and Lucas, W. J. 1997. Capsid protein and helper component-proteinase function as potyvirus cell-to-cell movement proteins. Virology 237:283-295.

Roudet-Tavert, G., Michon, T., Walter, J., Delaunay, T., Redondo, E., and Le Gall, O. 2007. Central domain of a potyvirus VPg is involved in the interaction with the host translation initiation factor eIF4E and the viral protein HcPro. J. Gen. Virol. 88:1029-1033.

Ruffel, S., Dussault, M.-H., Palloix, A., Moury, B., Bendahmane, A., Robaglia, C., and Caranta, C. 2002. A natural recessive resistance gene against Potato virus $Y$ in pepper corresponds to the eukaryotic initiation factor 4E (eIF4E). Plant J. 32:1067-1075.

Schaad, M. C., Jensen, P. E., and Carrington, J. C. 1997. Formation of plant RNA virus replication complexes on membranes: Role of an endoplasmic reticulum-targeted viral protein. EMBO (Eur. Mol. Biol. Organ.) J. 16:4049-4059.

Scholthof, K. G., Adkins, S., Czosnek, H., Palukaitis, P., Jacquot, E., Hohn, T., Hohn, B., Saunders, K., Candresse, T., Ahlquist, P., Hemenway, C., and Foster, G. D. 2011. Top 10 plant viruses in molecular plant pathology. Mol. Plant Pathol. 12:938-954.

Schwer, B. 2001. A new twist on RNA helicases: DExH/D box proteins as RNPases. Nat. Struct. Biol. 8:113-116.

Seo, J.-K., Lee, S.-H., and Kim, K.-H. 2009. Strain-specific cylindrical inclusion protein of Soybean mosaic virus elicits extreme resistance and a lethal systemic hypersensitive response in two resistant soybean cultivars. Mol. Plant-Microbe Interact. 22:1151-1159.

Seo, J.-K., Sohn, S.-H., and Kim, K.-H. 2011. A single amino acid change in HC-Pro of Soybean mosaic virus alters symptom expression in a soybean cultivar carrying Rsv1 and Rsv3. Arch. Virol. 156:135-141.

ShagaiMaroof, M. A, Tucker, D. M., Skoneczka, J. A., Bowman, B. C., Tripathy, S., and Tolin, S. A. 2010. Fine mapping and candidate gene discovery of the Soybean mosaic virus resistance gene, Rsv4. Plant Genome J. 3:14

Shand, K., Theodoropoulos, C., Stenzel, D., Dale, J. L., and Harrison, M. D. 2009. Expression of Potato virus $Y$ cytoplasmic inclusion protein in tobacco results in disorganization of parenchyma cells, distortion of epidermal cells, and induces mitochondrial and chloroplast abnormalities, formation of membrane whorls and atypical lipid a. Micron 40:730-736.

Suh, S. J., Bowman, B. C., Jeong, N., Yang, K., Kastl, C., Tolin, S. A., Maroof, M. A. S., and Jeong, S.-C. 2011. The Rsv3 locus conferring resistance to Soybean mosaic virus is associated with a cluster of coiled-coil nucleotide-binding leucine-rich repeat genes. Plant Genome J. 4:55.

Tavert-Roudet, G., Abdul-Razzak, A., Doublet, B., Walter, J., Delaunay, T., German-Retana, S., Michon, T., Le Gall, O., and Candresse, T. 2012. The $\mathrm{C}$ terminus of lettuce mosaic potyvirus cylindrical inclusion helicase interacts with the viral VPg and with lettuce translation eukaryotic initiation factor 4E. J. Gen. Virol. 93:184-193.

Tilsner, J., and Oparka, K. J. 2012. Missing links? The connection between replication and movement of plant RNA viruses. Curr. Opin. Virol. 2:705-711.

Truniger, V., and Aranda, M. A. 2009. Recessive Resistance to Plant Viruses. Pages 119-159 in: Advances in Virus Research, Vol. 75. Elsevier, Amsterdam.

Urcuqui-Inchima, S., Haenni, A.-L., and Bernardi, F. 2001. Potyvirus proteins: A wealth of functions. Virus Res. 74:157-175.

Vijayapalani, P., Maeshima, M., Nagasaki-Takekuchi, N., and Miller, W. A. 2012. Interaction of the trans-frame potyvirus protein P3N-PIPO with host protein PCaP1 facilitates potyvirus movement. PLoS Pathog. 8:e1002639. Published online.

Wang, A., and Krishnaswamy, S. 2012. Eukaryotic translation initiation factor 4E-mediated recessive resistance to plant viruses and its utility in crop improvement. Mol. Plant Pathol. 13:1-9.

Wei, T., and Wang, A. 2008. Biogenesis of cytoplasmic membranous vesicles for plant potyvirus replication occurs at endoplasmic reticulum exit sites in a COPI- and COPII-dependent manner. J. Virol. 82:1225212264 .

Wei, T., Huang, T.-S., McNeil, J., Laliberté, J.-F., Hong, J., Nelson, R. S., and Wang, A. 2010a. Sequential recruitment of the endoplasmic reticulum and chloroplasts for plant potyvirus replication. J. Virol. 84:799809.

Wei, T., Zhang, C., Hong, J., Xiong, R., Kasschau, K. D., Zhou, X., Carrington, J. C., and Wang, A. 2010b. Formation of complexes at plasmodesmata for potyvirus intercellular movement is mediated by the viral protein P3N-PIPO. PLoS Pathog. 6:e1000962. Published online.

Weintraub, M., and Ragetli, H. W. J. 1970. Distribution of viruslike particles in leaf cells of Dianthus barbatus infected with carnation vein mottle virus. Virology 40:868-881.

Wen, R.-H., and Hajimorad, M. R. 2010. Mutational analysis of the putative pipo of Soybean mosaic virus suggests disruption of PIPO protein impedes movement. Virology 400:1-7.

Wen, R.-H., Khatabi, B., Ashfield, T., Saghai Maroof, M. A., and Hajimorad, M. R. 2013. The HC-Pro and P3 cistrons of an avirulent Soybean mosaic virus are recognized by different resistance genes at the complex Rsv1 locus. Mol. Plant-Microbe Interact. 26:203-215.

Wittner, A., Palkovics, L., and Balázs, E. 1998. Nicotiana benthamiana plants transformed with the plum pox virus helicase gene are resistant to virus infection. Virus Res. 53:97-103.

YanHong, Q., DongMei, L., Tao, Z., and ZaiFeng, F. 2009. Immuno-localization of the CI protein of Sugarcane mosaic virus in the phloem cells of maize. Acta Phytophylac. Sin. 36:234-238.

Yeam, I., Cavatorta, J. R., Ripoll, D. R., Kang, B.-C., and Jahn, M. M. 2007. Functional dissection of naturally occurring amino acid substitutions in eIF4E that confers recessive potyvirus resistance in plants. Plant Cell 19:2913-2928.

Zechmann, B., Müller, M., and Zellnig, G. 2003. Cytological modifications in Zucchini yellow mosaic virus (ZYMV)-infected Styrian pumpkin plants. Arch. Virol. 148:1119-1133.

Zhang, C., Hajimorad, M. R., Eggenberger, A. L., Tsang, S., Whitham, S. A., and Hill, J. H. 2009. Cytoplasmic inclusion cistron of Soybean mosaic virus serves as a virulence determinant on Rsv3-genotype soybean and a symptom determinant. Virology 391:240-248.

Zilian, E., and Maiss, E. 2011. Detection of plum pox potyviral proteinprotein interactions in planta using an optimized mRFP-based bimolecular fluorescence complementation system. J. Gen. Virol. 92:27112723

\section{AUTHOR-RECOMMENDED INTERNET RESOURCE}

International Committee on Taxonomy of Viruses website: ictvonline.org/virusTaxonomy.asp 